\title{
Infection and Immunity
}

Early activation of splenic macrophages by tumor necrosis factor alpha is important in determining the outcome of experimental histoplasmosis in mice.

B A Wu-Hsieh, G S Lee, M Franco and F M Hofman Infect. Immun. 1992, 60(10):4230.

Updated information and services can be found at:

http://iai.asm.org/content/60/10/4230

These include:

CONTENT ALERTS Receive: RSS Feeds, eTOCs, free email alerts (when new articles cite this article), more» 


\title{
Early Activation of Splenic Macrophages by Tumor Necrosis Factor Alpha Is Important in Determining the Outcome of Experimental Histoplasmosis in Mice
}

\author{
BETTY A. WU-HSIEH, ${ }^{1 *}$ GER-SHUNG LEE,${ }^{1} \dagger$ MARCELLO FRANCO,${ }^{2}$ AND \\ FLORENCE M. HOFMAN ${ }^{3}$ \\ Department of Microbiology and Immunology, UCLA School of Medicine, Los Angeles, California 90024; \\ Faculdade de Medicina, Campus de Botucatu, Universidade Estadual Paulista, Botucatu-SP, Brazil2; \\ and Department of Pathology, University of Southern California School of Medicine, \\ Los Angeles, California $90033^{3}$
}

Received 17 January 1992/Accepted 8 July 1992

\begin{abstract}
Experimental infection of animals with Histoplasma capsulatum caused a massive macrophage infiltration into the spleen and induced the production of tumor necrosis factor alpha (TNF- $\alpha$ ) locally. The cytokine was also produced in vitro by peritoneal exudate macrophages exposed to a large inoculum of yeast cells. Depletion of the cytokine by injection of polyclonal sheep anti-TNF- $\alpha$ antibody was detrimental to sublethally infected mice. Fungous burdens in the spleens of TNF- $\alpha$-depleted mice were higher than they were in the infected control mice at days 2,7 , and 9 after infection, and the antibody-treated animals succumbed to the infection. Histopathological study of spleen sections revealed that splenic macrophages were not able to control proliferation of intracellular yeasts as a result of TNF- $\alpha$ depletion. It seems that TNF- $\alpha$ plays a role in early activation of splenic macrophages which is important in controlling the outcome of an infection.
\end{abstract}

The zoopathogenic fungus Histoplasma capsulatum is a facultative intracellular parasite of the mononuclear phagocytes of a host (43). Yeast cells of the fungus reside primarily in macrophages of the infected individual, and a cellular basis for acquired immunity to histoplasmosis is well documented in the experimental murine model (43). Adoptive transfer of lymphoid cells from immunized mice confers immunity to naive recipients and protects these mice from an otherwise lethal challenge $(33,37)$. Communication between lymphocytes and normal macrophages is effected by soluble protein(s) secreted into the culture supernatants, and one of these proteins is gamma interferon (IFN- $\gamma)(41,42)$. Recombinant murine IFN- $\gamma$ activates mouse resident peritoneal macrophages to inhibit the intracellular growth of $H$. capsulatum (42).

Smith et al. (30) have recently shown that another soluble protein, tumor necrosis factor alpha (TNF- $\alpha)$, is produced in response to $H$. capsulatum infection. TNF- $\alpha$ is found in bronchial lavage fluid of mice intranasally infected by $H$. capsulatum and by normal exudate macrophages after coculture with $H$. capsulatum yeast cells. They also reported that depletion of this cytokine accelerates mortality of infected animals (30).

The purpose of this study was to understand the functional role of TNF- $\alpha$ in host defense against $H$. capsulatum infection. By depleting the cytokine in question, we studied how the immune function of the host was compromised. We have shown that TNF- $\alpha$ was produced locally in infected spleens by macrophages and that depletion of this cytokine was detrimental to the infected host. It appears that depletion of TNF- $\alpha$ affected macrophage activation in the early phase of an infection and that such early activation had a great influence on the outcome of the disease.

\footnotetext{
* Corresponding author.

$\dagger$ Present address: Kaiser Regional Laboratory, Berkeley, CA 94710.
}

\section{MATERIALS AND METHODS}

Animals. Inbred male C57BL/6 mice were purchased from the Jackson Laboratory (Bar Harbor, Maine). Age-matched 6- to 9-week-old mice were used throughout the study.

Fungus. $H$. capsulatum UCLA 505 was used in the experiments. The yeast phase of the fungus was grown on bloodcysteine-glucose agar slants at $37^{\circ} \mathrm{C}$ for $72 \mathrm{~h}$ (41). In experiments in which yeast cells were used to induce TNF- $\alpha$ in vitro, the fungus was grown and passaged in HMM broth medium (39) on a rotary shaker. Cells were harvested, washed, and suspended in RPMI 1640 medium (GIBCO, Grand Island, N.Y.) for standardization. For sublethal infection, mice were injected intravenously with $2 \times 10^{6}$ yeast cells.

Antibody treatment of animals. Sheep polyclonal antimurine TNF- $\alpha$ antibody was kindly provided by Tom Leist, who at that time was in the Department of Microbiology \& Immunology, University of California, Los Angeles (15). A total of approximately $1.0 \times 10^{6}$ to $1.6 \times 10^{6}$ neutralizing units of anti-TNF- $\alpha$ antibody was given to mice intraperitoneally in four injections on days $0,1,3$, and 5 after infection with $H$. capsulatum or to normal uninfected mice. Immunocytochemical study (see "Immunohistocytochemical staining") of spleen sections from mice at 7 days after infection and 2 days after the last antibody injection confirmed that TNF- $\alpha$ was nearly completely depleted by such treatment. Other groups of mice included mice infected with the same inoculum of $\boldsymbol{H}$. capsulatum and given normal lamb serum and normal uninfected mice given normal lamb serum intraperitoneally according to the same schedule as that described above for anti-TNF- $\alpha$ antibody treatment.

Fungous burden in tissues. At days 2, 7, and 10 after infection, two mice from the appropriate groups were killed. The spleens were ground in a tissue grinder with $1 \mathrm{ml}$ of RPMI 1640 medium (GIBCO). Serial 1:10 dilutions were made from the tissue suspensions, and $0.1 \mathrm{ml}$ of each 
consecutive dilutions was plated on glucose-peptone agar (45). Colony counts (hyphal) were enumerated after incubation of plates at $30^{\circ} \mathrm{C}$ for 14 days.

Induction of TNF- $\alpha$ by $H$. capsulatum in vitro. Peritoneal exudate cells were collected from mice injected with $1 \mathrm{ml}$ of sterile mineral oil (Sigma, St. Louis, Mo.) 3 days before harvest. Approximately $8 \times 10^{5}$ cells were seeded into each well of flat-bottom 96-well plates, and the cells were allowed to adhere for $5 \mathrm{~h}$. Monolayers were washed and incubated overnight in RPMI 1640 medium with $10 \%$ heat-inactivated fetal bovine serum (Hyclone, Logan, Utah). The endotoxin level in the batch used in the experiments was $19 \mathrm{pg} / \mathrm{ml}$ of serum. $H$. capsulatum yeast cells were harvested from HMM broth culture and washed. Five million yeast cells suspended in $0.1 \mathrm{ml}$ of the RPMI 1640 medium described above were added to each well. Lipopolysaccharide (LPS; a trichloroacetic acid extract from Escherichia coli serotype O26:B6; Sigma) at $20 \mu \mathrm{g} / \mathrm{ml}$ was added to selected wells. Controls included wells containing LPS pretreated with polymyxin B sulfate (Sigma) or $\boldsymbol{H}$. capsulatum pretreated with polymyxin B sulfate (for $1 \mathrm{~h}$ at room temperature). Culture supernatants from wells with the same inducing agent or controls were pooled and spun down at designated times, and supernatants were collected. These supernatants were stored at 4 to $8^{\circ} \mathrm{C}$ before assay. Bioassays were always done within the same week.

Phenotyping of peritoneal exudate cells. To determine the phenotype of cells that produced TNF- $\alpha$ in vitro, peritoneal exudate cells were allowed to adhere for $2 \mathrm{~h}$ on Formvarcoated coverslips. Monolayers were washed with Hanks buffer solution containing $1 \%$ heat inactivated fetal bovine serum and $0.1 \%$ sodium azide. Two hundred microliters of neat supernatant from F4/80 hybridoma cultures (1) (rat immunoglobulin G2b [IgG2b], specific for $160,000-M_{\mathrm{r}}$ surface antigen on mature mouse macrophages in various tissues; ATCC HB 198) was added to the monolayers. After $1 \mathrm{~h}$ at $4^{\circ} \mathrm{C}$, monolayers were washed and overlaid with $200 \mu \mathrm{l}$ of affinity-isolated R-phycoerythrin-conjugated goat anti-rat IgG $(\mathbf{H}+\mathbf{L})$ (Caltag Laboratories, South San Francisco, Calif.) at a 1:10 dilution. After another $1 \mathrm{~h}$ at $4^{\circ} \mathrm{C}$, monolayers were again washed and fixed in $1 \%$ paraformaldehyde. Control coverslips were stained with the secondary antibody alone without the use of primary antibody. Monolayers were read in fluorescent microscope to score the percentage of positively stained cells. At least 200 cells per coverslip were read. Fluorescence in the control monolayers was negative.

TNF assay. (i) Bioassay. Fibrosarcoma cell lines $\mathrm{Lm}(\mathrm{S})$ and Lm(R) were a gift from Elizabeth Carswell and Barbara Williamson (Memorial Sloan-Kettering Cancer Center, New York, N.Y.). The two cell lines are sensitive $[\mathrm{Lm}(\mathrm{S})]$ or resistant $[\mathrm{Lm}(\mathrm{R})]$ to lysis by TNF- $\alpha$ (38). Ten thousand $\mathrm{Lm}(\mathrm{S})$ cells or fifteen thousand $\mathrm{Lm}(\mathrm{R})$ cells in $100 \mu \mathrm{l}$ were seeded in flat-bottom 96-well plates. After overnight incubation, culture supernatants at different dilutions and recombinant murine TNF- $\alpha$ (Genzyme, Boston, Mass.) at 5, 10, and $20 \mathrm{U} / \mathrm{ml}$ in combination with actinomycin D (final concentration of $1 \mu \mathrm{g} / \mathrm{ml}$ ) were added to wells containing $\mathrm{Lm}(\mathrm{S})$ and $\mathrm{Lm}(\mathrm{R})$ cells. Cultures were incubated for another $20 \mathrm{~h}$ before $20 \mu \mathrm{l}$ of MTT [3(4,5-dimethyl-thiazol-2yl)2,5diphenyl-tetrazolium bromide; Sigma] dye at $5 \mathrm{mg} / \mathrm{ml}$ was added. A 4-h incubation at $37^{\circ} \mathrm{C}$ was allowed for dye reduction by viable cells. Supernatants were decanted, and acidified isopropyl alcohol was added to the wells to solubilize and dissolve the reduced dye. The $A_{540}$ of the samples was measured in a Titertek Multiskan MCC/340 reader
(Flow Laboratories, Inc., McLean, Va.). Percent cell viability was calculated on the basis of comparison to the cell control. A standard curve was established with recombinant TNF- $\alpha$ at 5,10 , and $20 \mathrm{U} / \mathrm{ml}$ in each experiment so that the actual level of TNF- $\alpha$ in each sample could be determined. Diluted supernatants which caused $50 \%$ lysis of $\mathrm{Lm}(\mathrm{S})$ and no lysis of $\mathrm{Lm}(\mathrm{R})$ cells were considered to contain $1 \mathrm{U}$ of TNF- $\alpha$ per well $(0.1 \mathrm{ml})$, or $10 \mathrm{U} / \mathrm{ml}$.

(ii) ELISA. The TNF- $\alpha$ level in spleen cell supernatants (41) was determined by an enzyme-linked immunosorbant assay (ELISA) (Genzyme Corp.). Three antibodies-(i) hamster monoclonal anti-murine TNF antibody, (ii) goat polyclonal anti-murine TNF antibody, and (iii) donkey antigoat Ig-were used to sandwich TNF present in the samples. Peroxidase enzyme acting on a peroxide substrate and a chromogen $o$-phenylenediamine were used to detect bound TNF. Increased $A_{490}$ due to bound, immunoreactive TNF was quantified with a Titertek MCC/340 reader. The TNF concentration in experimental samples was determined by comparison of their absorbance with that obtained from the known amount of TNF provided in the standard.

Assessment of growth-inhibitory activity of macrophages stimulated by recombinant TNF- $\alpha$. Resident peritoneal (42) and spleen (27) cells were harvested from normal mice. Macrophages were enriched by adherence on Formvarcoated coverslips in RPMI 1640 medium (GIBCO) containing $10 \%$ fetal bovine serum (Hyclone). Recombinant murine TNF- $\alpha$ (Genzyme) at various concentrations was added to the monolayer. After $18 \mathrm{~h}$ of pretreatment, an inoculum of $H$. capsulatum yeast cells was added to the monolayer for phagocytosis in the presence of TNF- $\alpha$. The monolayers were washed free of extracellular yeasts after $2 \mathrm{~h}$ of incubation. The control monolayer cultured in medium was fixed in methanol at this time point $\left(T_{0}\right)$ as a baseline for calculation of growth. The rest of the monolayers were incubated for another $18 \mathrm{~h}\left(T_{18}\right)$ in media containing various concentrations of TNF- $\alpha$ or in medium alone. At the end of incubation, the monolayers were washed and fixed in methanol. The difference in the number of intracellular yeast cells between $T_{0}$ and $T_{18}$ was recorded as growth. Percent inhibition of growth was calculated as $(1-$ growth in TNF- $\alpha$-treated monolayers divided by the growth in medium alone) $\times$ $100 \%$.

Immunohistocytochemical staining. Spleens from mice were snap frozen in liquid nitrogen immediately after removal from the animals and then stored at $-70^{\circ} \mathrm{C}$. The processing and staining procedure has been published previously $(17,18)$. Briefly, cryostat sections, 8 to $10 \mu \mathrm{m}$ in thickness, were cut, dried overnight, and fixed in reagentgrade acetone for $5 \mathrm{~min}$ at $25^{\circ} \mathrm{C}$. The slides were stained with a primary antibody-polyclonal rabbit anti-mouse TNF- $\alpha$ at room temperature (IgG and IgM; Genzyme) or monoclonal rat anti-mouse macrophage antibody (rat IgG, neat supernatant from hybridoma F4/80), anti-L3T4 monoclonal antibody (rat IgG2b heavy chain; Becton Dickinson, Burlingame, Calif.), or anti-Lyt-2 monoclonal antibody (rat IgG2a heavy and light chains; Becton Dickinson) at $37^{\circ} \mathrm{C}$-for $30 \mathrm{~min}$ in a humidified chamber. The slides were then washed in phosphate-buffered saline (PBS) and incubated with biotin-labeled secondary antibody for another $30 \mathrm{~min}$. An avidinbiotin-peroxidase complex (Vector Laboratories Inc., Burlingame, Calif.) was added to the slides and incubated for $20 \mathrm{~min}$. The substrate aminoethyl carbazole was then applied to the slides. The slides were washed $10 \mathrm{~min}$ later in tap water, stained in Mayer's hematoxylin for $1 \mathrm{~min}$, and mounted in a glycerol-PBS mixture (1:1). Normal rabbit 

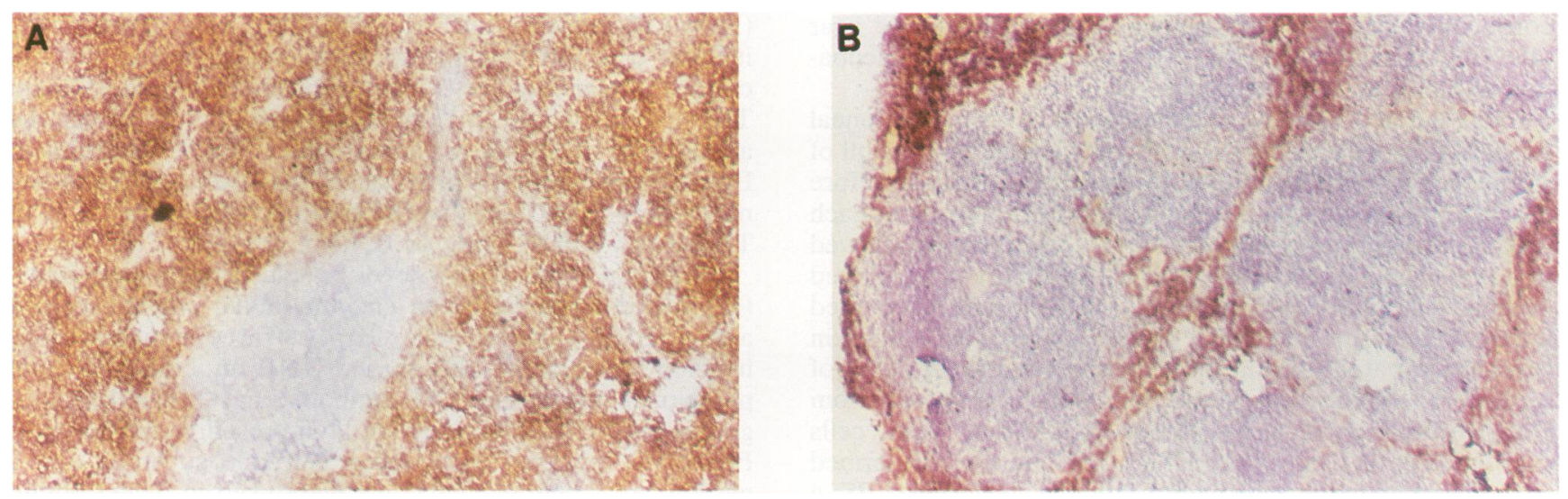

FIG. 1. Macrophage infiltration in spleen of $H$. capsulatum-infected mouse. Spleen sections from a mouse infected 7 days previously by $H$. capsulatum (A) and a normal mouse (B) were stained with the macrophage marker F4/80 monoclonal antibody (magnification, $\times 66$ ).
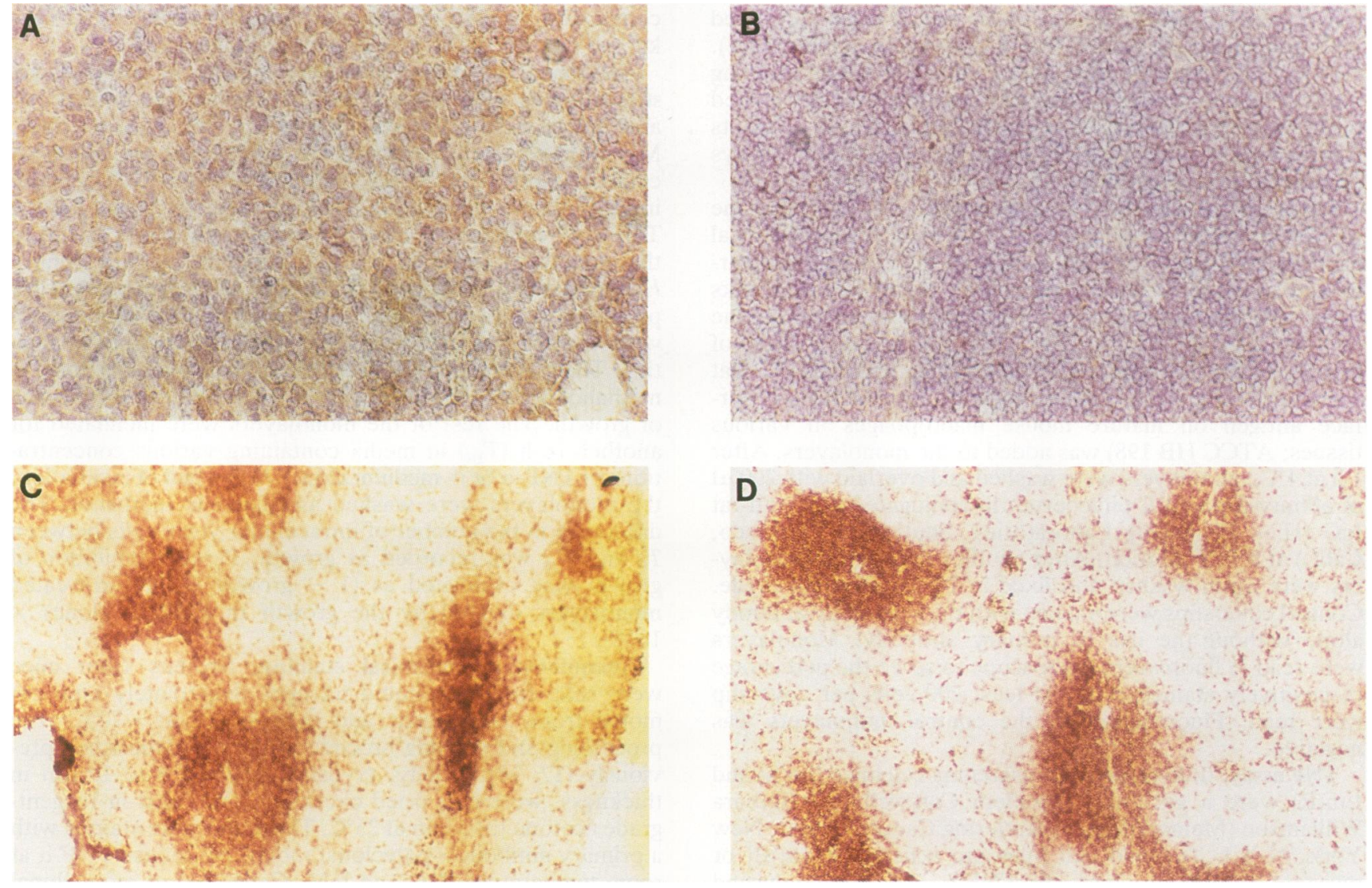

FIG. 2. Depletion of $T$ cells in spleen of $H$. capsulatum-infected mouse. Spleen sections from $H$. capsulatum-infected mice at 7 days after injection were stained with anti-CD4 (A) and anti-CD8 (B) antibody, and those from control uninfected mice were stained with anti-CD4 (C) and anti-CD8 (D) antibody in a similar manner (magnification, $\times 66$ ).

serum and isotype-matched irrelevant anti-mouse antibodies in place of specific antibodies were used as controls for staining. The staining was negative for all the groups tested.

Histology. The response to infection with $H$. capsulatum and the effect of antibody treatment on that response were assessed in sections of spleen. The spleens were fixed in $10 \%$ buffered formaldehyde. The sections were stained with hematoxylin-eosin.

\section{RESULTS}

Infection by $\boldsymbol{H}$. capsulatum changes the distribution of cells in the spleen. Yeast cells of $H$. capsulatum injected intravenously into mice proliferate for a time as facultative intracellular parasites of macrophages. Three to six days after infection, host cells begin to migrate from the thymus, bone marrow, and peripheral blood to the spleen of each animal, 

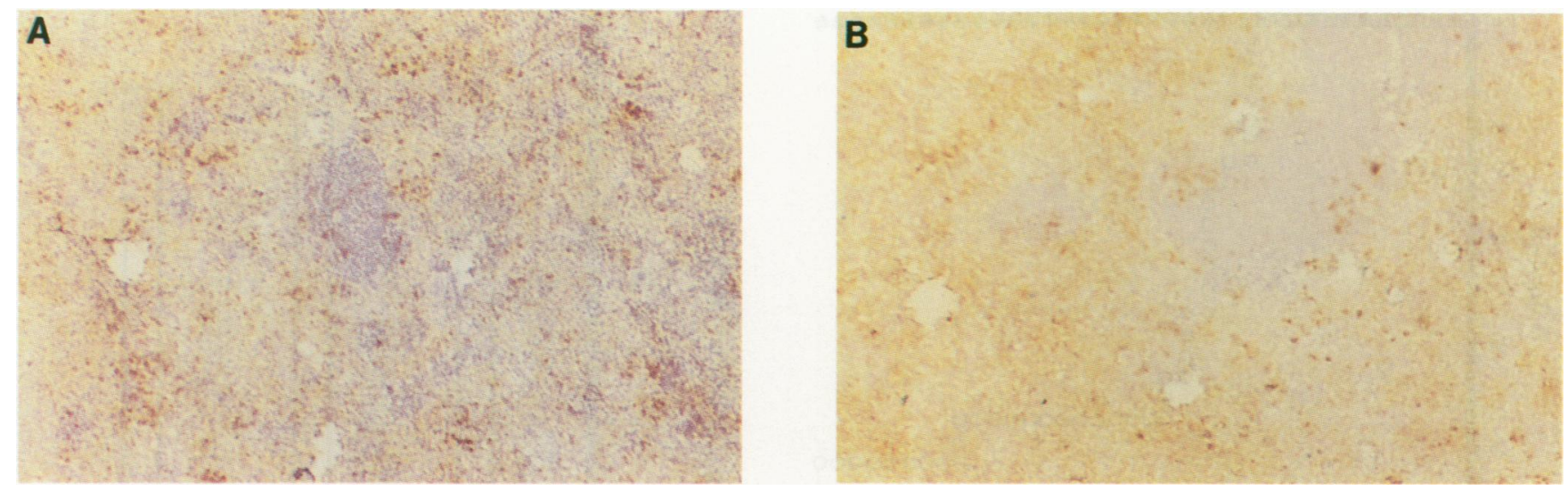

FIG. 3. In situ production of TNF- $\alpha$ in spleen of $H$. capsulatum-infected mouse. Spleen sections from a mouse infected 7 days previously by $H$. capsulatum (A) and a control uninfected mouse (B) were stained for TNF- $\alpha$ (magnification, $\times 66$ ).

a migration that results in a developing splenomegaly which reaches a peak 2 to 3 weeks after infection $(36,45)$. Our results show that this characteristic splenomegaly was a result of changes in the distribution of cells in the spleen. Immunocytochemically stained spleen sections from mice 7 days after injection are shown in Fig. 1. It is revealed that there was an apparent expansion of the macrophage population (Fig. 1A). Such a histological picture was in marked contrast to that in the controls (Fig. 1B), in which macrophages were confined to the marginal zones. The change of macrophage distribution was accompanied by one in the lymphocyte population as well (Fig. $2 \mathrm{~A}$ and $\mathrm{B}$ ). The numbers of $\mathrm{CD}^{+}$and $\mathrm{CD8}^{+} \mathrm{T}$ cells were low and were sparsely scattered throughout the spleens of infected mice. In contrast, both $\mathrm{CD}^{+}$and $\mathrm{CD} 8^{+} \mathrm{T}$ cells were present in large numbers and were arranged in the customary follicular pattern in normal spleens (Fig. 2C and D). The histological pictures presented here demonstrate that $H$. capsulatum caused an accumulation of macrophages and a depletion of $T$ cells in the spleen. It seems likely that cytokines produced by the macrophages would have an influence on the disease.

TNF- $\alpha$ is produced locally in the spleen of an animal host experimentally infected by $\boldsymbol{H}$. capsulatum. We demonstrated by immunocytochemistry that mice experimentally infected by $H$. capsulatum produced TNF- $\alpha$ in their spleens (Fig. $3 A)$. Regions that stained positive for TNF- $\alpha$ appeared to coincide with the overwhelming presence of macrophage in the infected spleen. It seemed that the staining was most prominent in the intercellular spaces, which suggested that anti-TNF- $\alpha$ antibody was binding to a secreted product and was not associated with any particular cell. Staining of normal spleens showed that the intensity of TNF- $\alpha$ staining was much less (Fig. 3B) than that in the infected tissue (Fig. 3A). An ELISA was used to document quantitatively the level of TNF- $\alpha$ in infected spleens. Ten million spleen cells from mice 7 days after infection by $H$. capsulatum produced 1,000 to $1,500 \mathrm{pg}$ of TNF- $\alpha$ per $\mathrm{ml}$ in culture supernatants, while normal uninfected controls produced a background level of approximately 120 to $190 \mathrm{pg} / \mathrm{ml}$. The range of TNF- $\alpha$ reported was that among four infected or four normal mice.

TNF- $\alpha$ is produced in vitro by macrophages stimulated by $H$. capsulatum yeast cells. It was clear that TNF- $\alpha$ was produced locally in an infected spleen. However, it was not demonstrated directly which cell population was responsible for its production. Data shown in Table 1 demonstrate that the adherent macrophage populations were responsive to in vitro stimulations by $H$. capsulatum as well as LPS to produce TNF- $\alpha$. Peritoneal exudate cells elicited by mineral oil injection were allowed to adhere to the plastic chamber overnight. The adherent cells were then stimulated with $H$. capsulatum yeast cells, with yeast cells pretreated with polymyxin B, with LPS, or with LPS pretreated with polymyxin B. Both LPS and $H$. capsulatum yeast cells induced the production of TNF- $\alpha$ as measured by bioactivity in the TNF- $\alpha$-sensitive $[\mathrm{Lm}(\mathrm{S})]$ and -resistant $[\mathrm{Lm}(\mathrm{R})]$ cell lines. The production of TNF- $\alpha$ induced by LPS and by $H$. capsulatum followed a different time course, and the levels of activity were different. LPS-induced production of TNF- $\alpha$ reached its peak $(113.0 \pm 14.1 \mathrm{U} / \mathrm{ml})$ as early as $2 \mathrm{~h}$ after stimulation. The level of TNF- $\alpha$ activity dropped to half $(56.5 \pm 14.1 \mathrm{U} / \mathrm{ml})$ by $16 \mathrm{~h}$ in culture. The peak of TNF- $\alpha$

TABLE 1. Production of TNF- $\alpha$ by peritoneal exudate cells ${ }^{a}$ stimulated with $H$. capsulatum

\begin{tabular}{|c|c|c|}
\hline Stimulant & $\begin{array}{l}\text { Time in } \\
\text { culture } \\
(\mathrm{h})^{b}\end{array}$ & $\begin{array}{l}\text { TNF- } \alpha \text { level } \\
(\mathrm{U} / \mathrm{ml})^{c}\end{array}$ \\
\hline LPS $^{d}$ & $\begin{array}{r}2 \\
4 \\
16\end{array}$ & $\begin{array}{r}80.0 \pm 10.7 \\
113.0 \pm 14.1 \\
56.0 \pm 14\end{array}$ \\
\hline LPS + polymyxin $\mathrm{B}^{e}$ & $\begin{array}{r}10 \\
2 \\
4 \\
16\end{array}$ & $\begin{array}{l}50.0 \pm 14.1 \\
<2.0 \\
<2.0 \\
<3.2\end{array}$ \\
\hline H. capsulatum ${ }^{f}$ & $\begin{array}{r}4 \\
16 \\
24\end{array}$ & $\begin{aligned} 139.3 & \pm 24.6 \\
1,280.0 & \pm 26.4 \\
519.8 & \pm 23.0\end{aligned}$ \\
\hline H. capsulatum + polymyxin $\mathrm{B}^{e}$ & $\begin{array}{r}4 \\
16 \\
24\end{array}$ & $\begin{aligned} \text { ND } & \\
1,039.7 & \pm 32.5 \\
519.8 & \pm 42.8\end{aligned}$ \\
\hline
\end{tabular}

${ }^{a}$ Approximately $8 \times 10^{5}$ peritoneal exudate cells were added to each well.

$b$ Supernatants were collected after peritoneal exudate cells were incubated with stimulants for the designated time.

${ }^{c}$ TNF- $\alpha$ levels were assayed in cell cultures of $\operatorname{Lm}(\mathbf{S})$ and $\operatorname{Lm}(\mathrm{R})$ (see Materials and Methods) and are the means plus or minus the standard deviations. Each determination was the average of results from three experiments. ND, not done.

${ }^{d}$ One hundred microliters of LPS at $20 \mu \mathrm{g} / \mathrm{ml}$ was added to the wells.

e Polymyxin B at $40 \mu \mathrm{g} / \mathrm{ml}$ was mixed with $20 \mu \mathrm{g}$ of LPS or Histoplasma yeast cells per $\mathrm{ml}$ and incubated at room temperature for $1 \mathrm{~h}$ before being added to wells.

${ }^{f}$ Five million $H$. capsulatum yeast cells in $0.1 \mathrm{ml}$ were added to wells. 


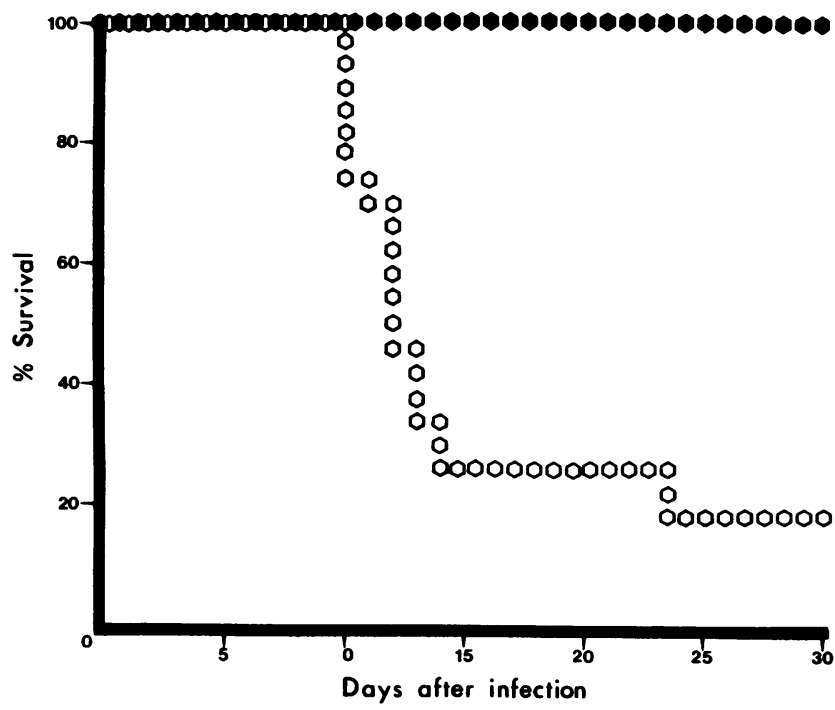

FIG. 4. Anti-TNF- $\alpha$ antibody-treated mice succumbed to sublethal infection by $H$. capsulatum. Mice infected by $H$. capsulatum and given normal serum intraperitoneally (closed symbols) and infected mice given four injections of anti-TNF- $\alpha$ antibody (open symbols) were observed for survival up to $\mathbf{3 0}$ days after infection. Twelve mice were included in each group.

production induced by $H$. capsulatum yeast cells was at $16 \mathrm{~h}$ after stimulation, and the level of activity was as high as $1,280 \pm 26.4 \mathrm{U} / \mathrm{ml}$. Since samples of culture supernatants from either LPS- or $H$. capsulatum-stimulated cultures lysed the $\operatorname{Lm}(S)$ cells but not $\operatorname{Lm}(R)$ cells (data not shown), the active component in the culture supernatants was TNF- $\alpha$ and not a nonspecific toxin or TNF- $\beta$ (38). In addition, the data in Table 1 show that polymyxin $B$ neutralized the stimulating effect of LPS but not that of $H$. capsulatum yeast cells. This result confirmed that the ability of $H$. capsulatum to induce TNF- $\alpha$ production was not due to LPS contamination. Ninety percent of the cells composing the monolayers stained positive with F4/80 and phycoerythrin-conjugated goat anti-rat Ig. This result indicates that exudate cells producing TNF- $\alpha$ were of macrophage lineage (1).

TNF- $\alpha$ is essential to host resistance to experimental histoplasmosis. The importance of TNF- $\alpha$ produced during infection to recovery from histoplasmosis was demonstrated by depleting the cytokine at the time of and after infection. Mice were infected by a normally sublethal dose of $H$. capsulatum yeast cells intravenously. Half of them received multiple injections of anti-TNF- $\alpha$ antibody, and half received normal lamb serum intraperitoneally on days $0,1,3$, and 5 after infection. Animal survival was monitored for up to 30 days after infection. The data in Fig. 4 show that $100 \%$ of the mice given normal lamb serum after a sublethal dose of $\boldsymbol{H}$. capsulatum survived the infection. Most of the animals given anti-TNF- $\alpha$ antibody died within a short time (10 to 14 days) after infection. Only 1 of $12(17 \%)$ survived the infection beyond day 30 .

A heavy burden of fungus was found in the tissues of animals that died. As shown in Fig. 5, mice infected with a sublethal dose of $H$. capsulatum had $\log _{10} 6.4 \pm 0.2$ and $\log _{10}$ $6.4 \pm 0.2 \mathrm{CFU}$ of fungus per $\mathrm{g}$ of spleen on days 2 and 7 of infection. These animals reduced the number of fungi after day 7. By day 9 the counts became $\log _{10} 5.8 \pm 0.2$. Mice injected with anti-TNF- $\alpha$ antibody did not control the

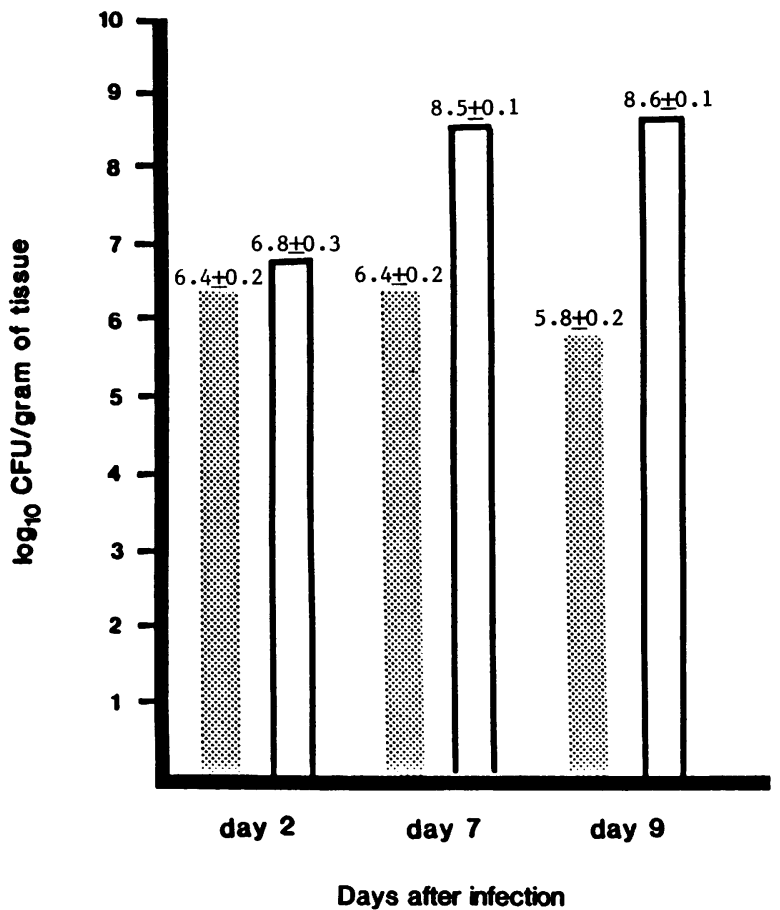

FIG. 5. Increased fungous burden in mice treated with antiTNF- $\alpha$ antibody. Fungous counts in $\log _{10}$ CFU per gram ( \pm standard errors of the mean) of tissue from $H$. capsulatum-infected mice (shaded bars) and infected mice treated with anti-TNF- $\alpha$ antibody (open bars) at days 2,7 , and 9 after infection. The numbers represent counts from six mice in each group.

growth of the fungus as did the control mice (given lamb serum). Fungous counts from spleens were more than $0.4 \mathrm{log}$ higher at day 2 and more than $2 \log$ higher at day 7 in the spleens of these mice than in their control counterparts (Fig. $5)$. The counts remained high in the spleens of antibodytreated mice, while the counts in the control mice were reduced at day 9 . The treated animals died shortly after the high counts were recorded (Fig. 4). These data clearly demonstrated that depletion of the endogenously produced TNF- $\alpha$ in $H$. capsulatum-infected animals diminished the host's ability to recover from experimental histoplasmosis.

Uncontrolled proliferation of intracellular yeasts as a result of TNF- $\alpha$ depletion in $\boldsymbol{H}$. capsulatum-infected mice. Figure 6 shows the histopathological picture of the spleen sections from $H$. capsulatum-infected mice and infected mice treated with anti-TNF- $\alpha$ antibody at 7 days after infection. $H$. capsulatum infection resulted in a large number of nodules made up of inflammatory cells and located predominantly in the red pulp. The cells showed clear nuclei and ill-demarcated cytoplasm, and they seemed to be macrophages and lymphocytes. Small foci of necrosis and small accumulations of neutrophils were not infrequently observed. The reaction was classified as a mature granuloma with the tendency toward the epithelioid type. In the central area of some of the inflammatory foci, there were macrophages with limited numbers of $H$. capsulatum yeast cells in the cytoplasm (Fig. 6A). The inflammatory pattern in the spleens from antibodytreated animals was similar to that observed in spleens from untreated animals. However, the granulomata were more extensive, edematous, and exudative. The macrophages were loosely arranged in the granuloma, and the number of 

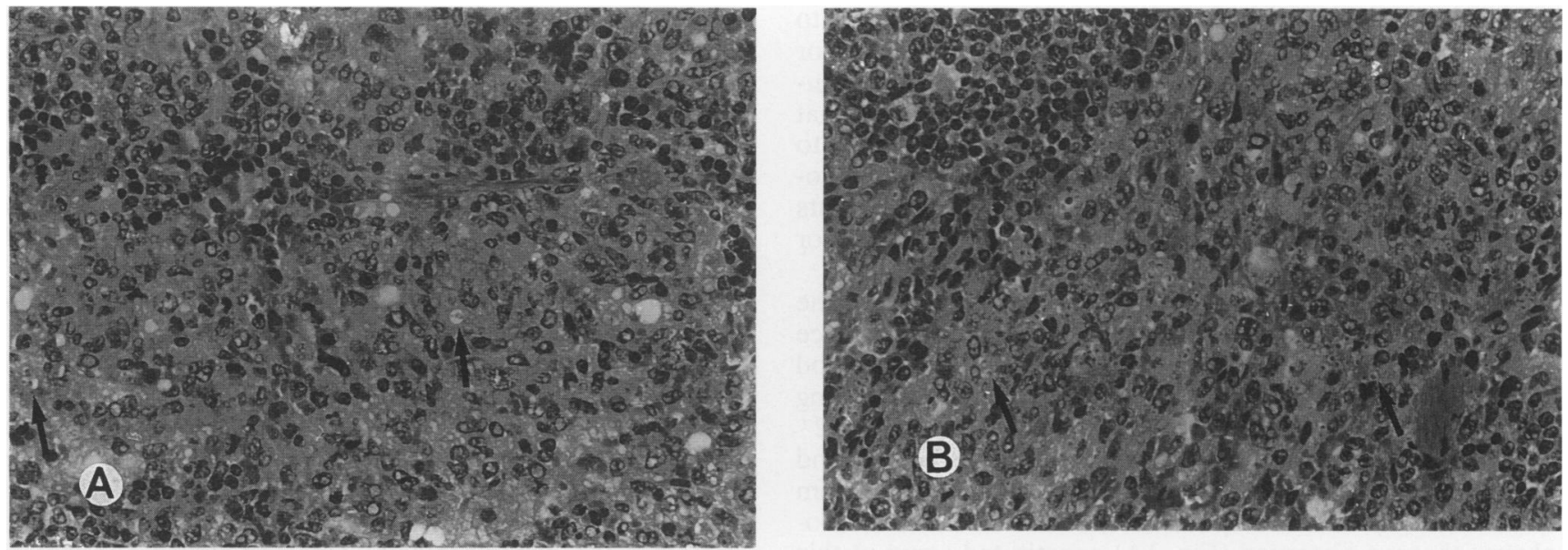

FIG. 6. Uncontrolled proliferation of $H$. capsulatum in spleen macrophages of antibody-treated animals. Hematoxylin-eosin stain of spleen sections from a mouse infected by $H$. capsulatum (A) and an infected mouse treated with anti-TNF- $\alpha$ antibody (B). Arrows point to H. capsulatum yeast cells in the cytoplasm of macrophages.

neutrophils was increased. Most obviously, the number of fungi was much greater. The fungal cells were located mainly inside the cytoplasm of the macrophages (Fig. 6B). Comparing the number of intracellular yeasts in splenic macrophages from sublethally infected mice (Fig. 6A) and infected mice with antibody treatment (Fig. 6B), it is obvious that macrophages in antibody-treated animals did not restrict proliferation of the fungus. The histological picture displayed in the liver was similar to that observed in the spleens (data not shown).

Recombinant TNF- $\alpha$ does not efficiently activate macrophages to an antihistoplasma state. The lack of TNF- $\alpha$ affected the ability of animals to clear $H$. capsulatum from their tissues. We proceeded to determine whether this cytokine had a direct effect on yeast cell growth within macrophages in vitro. Results of such experiments are recorded in Table 2 . The levels of TNF- $\alpha$ used spanned a wide range, from 5 to $20,000 \mathrm{U} / \mathrm{ml}$. Growth of yeast cells in

TABLE 2. Effect of TNF- $\alpha$ on macrophage antihistoplasma activity

\begin{tabular}{|c|c|c|c|c|}
\hline $\begin{array}{c}\text { Source of } \\
\text { macrophages }\end{array}$ & $\begin{array}{c}\text { TNF- } \alpha \\
\text { level } \\
(\mathrm{U} / \mathrm{ml})^{a}\end{array}$ & $\begin{array}{c}\text { Mean no. of yeast } \\
\text { cells/infected } \\
\text { macrophage } \\
\text { at } T_{18}\end{array}$ & Growth $^{b}$ & $\begin{array}{c}\% \text { Inhibition } \\
\text { of growth }\end{array}$ \\
\hline \multirow[t]{6}{*}{ Peritoneum } & 0 & $5.6 \pm 1.4$ & 3.7 & \\
\hline & 5 & $5.6 \pm 1.2$ & 3.7 & 0 \\
\hline & 200 & $5.9 \pm 1.0$ & 4.0 & 0 \\
\hline & 1,000 & $5.4 \pm 1.0$ & 3.5 & 5 \\
\hline & 5,000 & $5.2 \pm 0.7$ & 3.3 & 11 \\
\hline & 20,000 & $5.3 \pm 0.8$ & 3.4 & 8 \\
\hline \multirow[t]{2}{*}{ Spleen } & 0 & $7.0 \pm 0.8$ & 5.1 & \\
\hline & 2,000 & $6.8 \pm 0.9$ & 4.9 & 4 \\
\hline
\end{tabular}

a The activity of recombinant TNF- $\alpha$ was determined according to the information provided by the manufacturer for the specific lot.

${ }^{b}$ Growth is the difference in the mean numbers of yeast cells between $T_{18}$ and $T_{0}$. The number of yeast cells in peritoneal macrophages at $T_{0}$ is $1.9 \pm 0.2$, and that in splenic macrophages is $1.9 \pm 0.1$. The data on peritoneal and splenic macrophages were derived from separate experiments. The difference in intracellular growth in the two sorts of macrophages was not consistently seen in other experiments and reflects slight differences in experimental detail.

${ }^{c}$ Calculation of percent inhibition of growth is described in Materials and Methods. resident and splenic peritoneal macrophages stimulated by TNF- $\alpha$ in the concentrations used was not inhibited. Thus, it appears that TNF- $\alpha$ alone did not efficiently activate resident murine peritoneal or splenic macrophages to an antihistoplasma state.

\section{DISCUSSION}

It has been established in experimental histoplasmosis that $T$ cells from an immune animal transfer immunity against lethal challenge to a naive recipient and that such cells activate normal macrophages via soluble factor(s) $(19,41)$. One of the macrophage-activating factors that has been characterized is IFN- $\gamma(41,42)$. The $\mathrm{CD}^{+} \mathrm{T}$ cells in the spleen of an immune animal are responsible for the production of IFN- $\boldsymbol{\gamma}(40)$. Early production of IFN- $\gamma$ by a resistant mouse correlates with the ability to clear the infection (40). However, depletion of this cytokine did not result in death of sublethally infected animals, although the fungous burden was increased 10-fold (44). In this study, we have demonstrated that TNF- $\alpha$ is also produced in the spleens of mice infected by $H$. capsulatum and is a controlling element in the outcome of the infection. The depletion of TNF- $\alpha$ resulted in the death of sublethally infected animals and in an increase of the fungous burden in the tissues.

Mature tissue macrophages, such as pulmonary, hepatic, peritoneal, and bone marrow macrophages, but not monocytes in peripheral blood are known to be the major producers of cachectin (TNF- $\alpha$ ) in response to LPS $(5,8)$. Other cell types, like the $T$ lymphocytes and natural killer cells, can also produce this cytokine upon stimulation by calcium ionophores in conjunction with phorbol myristate acetate (7, 9). We show in this study by immunohistocytochemical staining that at 7 days after infection, macrophages infiltrated the spleen (Fig. 1A) and TNF- $\alpha$ was produced (Fig. $3 \mathrm{~A})$. It seems that the macrophage population that appears in the spleen after an infection was the result of an influx of migrating cells rather than an expansion of resident cells. In order to study whether elicited macrophages can be stimulated by $H$. capsulatum to produce TNF- $\alpha$, we employed mineral oil-induced peritoneal exudate cells because of our inability to obtain chemically elicited splenic macrophages. Results of such study presented in Table 2 show that these 
cells readily responded to $H$. capsulatum stimulation to produce TNF- $\alpha$. In fact, neither resident peritoneal (46) or splenic (24) macrophages produced TNF- $\alpha$ after $H$. capsulatum stimulation. Taking these together, we concluded that the producer of TNF- $\alpha$ in a mouse spleen in response to infection by $H$. capsulatum was most likely the macrophages, especially the influx population. More experiments need to be done to determine whether $\mathrm{T}$ lymphocytes or natural killer cells are involved.

Watson et al. reported a migration of cells from the thymuses, blood, and bone marrow to the spleens of mice with disseminated histoplasmosis (36). There is a good correlation of thymus involution and splenomegaly during the course of disease and an increase of Lyt- $1^{+}$and Lyt-2 $2^{+}$ cells in the spleen. However, the total number of Lyt-1 ${ }^{+}$and Lyt- $2^{+}$cells does not account for all the cells recovered from an enlarged spleen. It is possible that the influx of macrophages that we observed (Fig. 1A) constituted some of this disparity. Although we did not trace the migration of T cells, we demonstrated the overwhelming presence of macrophages in spleens of mice infected by $\boldsymbol{H}$. capsulatum. Thus, macrophages and their product(s) may play an important role in the pathogenesis of histoplasmosis.

It was important to confirm that the ability of $H$. capsulatum yeast cells to induce TNF- $\alpha$ in vitro was not due to possible contamination of LPS. Data presented in Table 1 show that TNF- $\alpha$ production patterns in response to the two stimuli were different. In response to LPS, soluble TNF- $\alpha$ levels reached a peak at $4 \mathrm{~h}$ but were reduced to half of that amount $16 \mathrm{~h}$ after exposure. This observation coincides with the reported kinetics of cachectin (TNF- $\alpha$ ) mRNA appearance (5). The concentration of cachectin mRNA rises to a detectable level within minutes after exposure to LPS and reaches a peak at 2 to $3 \mathrm{~h}$ after stimulation. Cachectin mRNA declines slowly to the level of noninduced cells after 15 to 20 $h$ of exposure despite the continuous presence of the inducing stimulus. The production of cachectin itself ceases within 4 to $6 \mathrm{~h}$ following contact with LPS. In contrast, the level of TNF- $\alpha$ produced in response to $H$. capsulatum stimulation reached a peak at $16 \mathrm{~h}$. Besides the difference in the kinetics, the amount of soluble TNF- $\alpha$ induced by these two stimuli differed by a magnitude of severalfold. In addition, polymyxin B neutralized the inducing effect of LPS but not that of $H$. capsulatum yeast cells. Thus, we concluded that $H$. capsulatum stimulated macrophages to produce TNF- $\alpha$ in vitro and that it was not due to LPS contamination.

It has been shown in other infections that TNF- $\alpha$ is induced and plays an important role in host defense. TNF- $\alpha$ production is induced in vitro by macrophages infected with Coccidioides immitis (29), and treatment of human mononuclear monocytes with recombinant human TNF- $\alpha$ results in killing of intracellular endospores of $C$. immitis (3). TNF- $\alpha$ is involved in host defense against Listeria monocytogenes $(15$, 16, 23, 26), Leishmania sp. (4, 25, 28, 34), Legionella pneumophila (6), and Trypanosoma cruzi $(10,32)$. In contrast, there are also reports on TNF- $\alpha$ as a mediator for pathological changes caused by Mycobacterium tuberculosis (31) and in cerebral malaria $(12-14,22)$. Resolution of these seemingly contradicting effects awaits further study.

The roles of TNF- $\alpha$ in host defense are various. For example, macrophages activated by TNF- $\alpha$ kill Leishmania and Listeria spp. $(21,25)$ but only inhibit intracellular multiplication of $T$. cruzi and have no effect on Toxoplasma gondii (10). Bancroft et al. demonstrated that TNF- $\alpha$ activates macrophages in scid mice in a $\mathrm{T}$-cell-independent pathway (2). We conducted experiments to investigate the macrophage-activating activity of TNF- $\alpha$ by treating resident peritoneal and splenic red pulp macrophages with recombinant murine TNF- $\alpha$. Results of such experiments recorded in Table 2 showed that TNF- $\alpha$ alone did not activate either peritoneal or splenic macrophages to an impressive antihistoplasma state. However, preliminary data from an ongoing study of splenic macrophages showed that activation of these macrophages requires two signals, one of which can be recombinant TNF- $\alpha$ (24).

The histopathological pictures recorded in Fig. 6 displayed that splenic macrophages in animals depleted of TNF- $\alpha$, in contrast to those in the control animals, did not have the ability to restrict proliferation of intracellular $H$. capsulatum. This result and that presented in Table 2 suggest that TNF- $\alpha$ does not activate by itself but that it is required, possibly as a priming agent, in activation of splenic macrophages which are in the front line of host defense against disseminated histoplasmosis. This conclusion is substantiated by data shown in Fig. 5. The fungous burden in mice treated with anti-TNF- $\alpha$ antibody was greater than that in the untreated control mice as early as 2 days after infection. The difference of fungous counts became wider between the two groups at later time points. The inability to prime macrophages at this early time point before the production of IFN- $\gamma$ by $\mathrm{CD}^{+}{ }^{+} \mathrm{T}$ cells (40) appears to have contributed to the overwhelming outcome of the sublethal infection.

TNF- $\alpha$ along with interleukin- 1 and interleukin- 6 has been associated with inflammation and granuloma formation. The combination of cytokines causes neutrophil migration and accumulation and edema formation during inflammation (11, $20,35)$. Depletion of TNF- $\alpha$ in Listeria-infected mice diminishes the involvement of mononuclear cells in the infected foci in the liver, in contrast to granulomata which are populated by large numbers of mononuclear cells in control mice (16). We have shown in this study that depletion of TNF- $\alpha$ in $H$. capsulatum-infected animals did not change the inflammatory pattern in the spleen nor the liver but that the granulomata were more extensive, edematous, and exudative in the cytokine depleted-animals.

We have confirmed the observation by Smith et al. (30) that TNF- $\alpha$ is important in host defense against experimental histoplasmosis. We provide evidence to suggest that TNF- $\alpha$ is produced by macrophages in the infected spleen and that depletion of this cytokine affected the ability of macrophages to control proliferation of the intracellular fungus and thus affected the ability of the animal to control infection by $H$. capsulatum.

\section{ACKNOWLEDGMENTS}

We are thankful to Dexter $\mathrm{H}$. Howard for reading the manuscript and providing helpful comments and to Sylvia Odesa and Scott McCallum for their excellent technical assistance. The generous gift of polyclonal sheep anti-TNF- $\alpha$ antibody from Tom Leist is gratefully acknowledged.

These studies were supported by funds from Public Health Service grants AI-22963 (B.W.-H.) and EYO 8144 (F.M.H.) from the National Institutes of Health.

\section{REFERENCES}

1. Austyn, J. M., and S. Gordon. 1981. F4/80, a monoclonal antibody directed specifically against the mouse macrophage. Eur. J. Immunol. 11:805-815.

2. Bancroft, G. J., K. C. F. Sheehan, R. D. Schreiber, and E. R. Unanue. 1989. Tumor necrosis factor is involved in the $T$ cell-independent pathway of macrophage activation in scid mice. J. Immunol. 143:127-130.

3. Beaman, L. 1991. Effects of recombinant gamma interferon and 
tumor necrosis factor on in vitro interactions of human.mononuclear phagocytes with Coccidioides immitis. Infect. Immun. 59:4227-4229.

4. Belosevic, M., D. S. Finbloom, M. S. Meltzer, and C. A. Nacy. 1990. IL-2. A cofactor for induction of activated macrophage resistance to infection. J. Immunol. 145:831-839.

5. Beutler, B., and A. Cerami. 1988. Tumor necrosis, cachexia, shock, and inflammation: a common mediator. Annu. Rev. Biochem. 57:505-518.

6. Blanchard, D. K., J. Y. Djeu, T. W. Klein, H. Friedman, and W. E. Stewart III. 1988. Protective effects of tumor necrosis factor in experimental Legionella pneumophila infections of mice via activation of PMN function. J. Leukocyte Biol. 43:429_ 435.

7. Cuturi, M. C., M. Murphy, M. P. Costa-Giomi, R. Weinmann, B. Perussia, and G. Trinchieri. 1987. Independent regulation of tumor necrosis factor and lymphotoxic production by human peripheral blood lymphocytes. J. Exp. Med. 165:1581-1594.

8. Decker, T., M.-L. Lohmann-Matthes, and G. E. Gifford. 1987. Cell-associated tumor necrosis factor (TNF) as a killing mechanism of activated cytotoxic macrophages. J. Immunol. 138: 957-962.

9. Degliantoni, G., M. Murphy, M. Kobayashi, M. K. Francis, B. Perussia, and G. Trinchieri. 1985. Natural killer (NK) cellderived hematopoietic colony-inhibiting activity and NK cytotoxic factor. Relationship with tumor necrosis factor and synergism with immune interferon. J. Exp. Med. 162:1512-1530.

10. DeTitto, E. H., J. R. Catterall, and J. S. Remington. 1986. Activity of recombinant tumor necrosis factor on Toxoplasma gondii and Trypanosoma cruzi. J. Immunol. 137:1342-1345.

11. Faccioli, L. H., G. E. Souza, F. Q. Cunha, S. Poole, and S. H. Ferreira. 1990. Recombinant interleukin-1 and tumor necrosis factor induce neutrophil migration "in vivo" by indirect mechanisms. Agents Actions 30:344-349.

12. Grau, G. E., L. F. Fajardo, P. F. Piguet, B. Allet, and P. H. Lambert. 1987. Tumor necrosis factor (cachectin) as an essential mediator in murine cerebral malaria. Science 237:1210-1212.

13. Grau, G. E., H. Heremans, P. F. Piguet, P. Pointaire, P. H: Lambert, A. Billiau, and P. Vassalli. 1989. Monoclonal antibody against interferon $\gamma$ can prevent experimental cerebral malaria and its associated overproduction of tumor necrosis factor. Proc. Natl. Acad. Sci. USA 86:5572-5574.

14. Grau, G. E., T. E. Taylor, M. E. Molyneux, J. J. Winima, P. Vassalli, M. Hommel, and P. H. Lambert. 1989. Tumor necrosis factor and disease severity in children with falciparum malaria. N. Engl. J. Med. 320:1586-1591.

15. Hauser, T., K. Frel, R. M. Zinkernagel, and T. P. Leist. 1990. Role of tumor necrosis factor in Listeria resistance in nude mice. Med. Microbiol. Immunol. 179:95-104.

16. Havell, E. A. 1989. Evidence that tumor necrosis factor has important role in antibacterial resistance. J. Immunol. 143:2894 2899.

17. Hofman, F. M., D. Hinton, K. Johnson, and J. E. Merrill. 1989. Tumor necrosis factor identified in multiple sclerosis brain. $\mathrm{J}$. Exp. Med. 170:607-612.

18. Hofman, F. M., D. R. Hinton, M. Weil, J. Baemayr, and J. E. Merrill. 1991. Lymphokines and immunoregulatory molecules in subacute sclerosing panencephalitis. Clin. Immunol. Immunopathol. 58:331-342.

19. Howard, D. H., V. Otto, and R. K. Gupta. 1971. Lymphocytemediated cellular immunity in histoplasmosis. Infect. Immun. 4:605-610.

20. Kasahara, K., K. Kabayashi, Y. Shikama, I. Yoneya, S. Kaga, et al. 1989. The role of monokines in granuloma formation in mice: the ability of interleukin 1 and tumor necrosis factor- $\alpha$ to induce lung granulomas. Clin. Immunol. Immunopathol. 51:419-425.

21. Kato, K., A. Nakane, T. Minagawa, N. Kasai, K. Yamamoto, N. Sato, and N. Tsuruoka. 1989. Human tumor necrosis factor increases the resistance against Listeria infection in mice. Med. Microbiol. Immunol. 178:337-346.

22. Kern, P., C. J. Hemmer, J. Van Damme, H. J. Gruss, and M. Dietrich. 1989. Elevated tumor necrosis factor alpha and interleukin-6 serum levels as markers for complicated Plasmodium falciparum malaria. Am. J. Med. 87:139-143.

23. Kurlander, R. J., M. Hoffiman, S. S. Kratz, and J. Gates. 1989. Comparison of the effects of IL- $1 \alpha$ and TNF- $\alpha$ on phagocyte accumulation and murine autibacterial immunity. Cell. Immunol. 123:9-22.

24. Lane, T. E., B. A. Wu-Hsieh, and D. H. Howard. 1992. IFNgamma cooperates with LPS or TNF-alpha to activate mouse splenic macrophages to an antihistoplasma state, abstr. F-39, p. 505. Abstr. 92nd Gen. Meet. Am. Soc. Microbiol. 1992. American Society for Microbiology, Washington, D.C.

25. Liew, F. Y., C. Parkinson, S. Millott, A. Severn, and M. Carrier. 1990. Tumor necrosis factor (TNF $\alpha$ ) in leishmaniasis. I. TNF $\alpha$ mediates host protection against cutaneous leishmaniasis. Immunology 69:570-573.

26. Nakane, A., T. Minagawa, and K. Kato. 1988. Endogenous tumor necrosis factor (cachectin) is essential to host resistance against Listeria monocytogenes infection. Infect. Immun. 56: 2563-2569.

27. Nusrat, A. R., S. D. Wright, A. A. Aderem, R. M. Steinman, and Z. A. Cohn. 1988. Properties of isolated red pulp macrophages from mouse spleen. J. Exp. Med. 168:1505-1510.

28. Reiner, N. E., W. Ng, C. B. Wilson, W. R. McMaster, and S. K. Burchett. 1990. Modulation of in vitro monocyte cytokine responses to Leishmania donovani. Interferon-gamma prevents parasite-induced inhibition of interleukin production and primes monocytes to respond to Leishmania by producing both tumor necrosis factor-alpha and interleukin 1. J. Clin. Invest. 85:1914 1924

29. Slagle, D. C., R. A. Cox, and U. Kuraganti. 1989. Induction of tumor necrosis factor alpha by spherules of Coccidioides immitis. Infect. Immun. 57:1916-1921.

30. Smith, J. G., D. M. Magee, D. W. Williams, and J. R. Graybill. 1990. Tumor necrosis factor- $\alpha$ plays a role in host defense against Histoplasma capsulatum. J. Infect. Dis. 162:1349-1353.

31. Takashima, T., C. Ueta, I. Tsuyuguchi, and S. Kishimoto. 1990. Production of tumor necrosis factor alpha by monocytes from patients with pulmonary tuberculosis. Infect. Immun. 58:32863292.

32. Tarleton, R. L. 1988. Tumor necrosis factor (cachectin) production during experimental Chagas' disease. Clin. Exp. Immunol. 73:186-190.

33. Tewari, R. P., D. Sharma, M. Solotorovsky, R. Lafemina, and J. Balint. 1977. Adoptive transfer of immunity from mice immunized with ribosomes or live cells of Histoplasma capsulatum. Infect. Immun. 15:789-795.

34. Titus, R. G., B. Sherry, and A. Cerami. 1989. Tumor necrosis factor plays a protective role in experimental murine cutaneous leishmaniasis. J. Exp. Med. 170:2097-2104.

35. Wandowicz, Z., P. Megyeri, and A. Issekutz. 1988. Synergy between tumor necrosis factor $\alpha$ and interleukin-1 in the induction of polymorphonuclear leukocyte migration during inflammation. J. Leukocyte Biol. 43:349-356.

36. Watson, S. R., T. B. Miller, T. J. Redington, and W. G. Bullock. 1983. Immunoregulation in experimental disseminated histoplasmosis: flow microfluorometry (FMF) studies of the thy and lyt phenotypes of $T$ lymphocytes from infected mice. J. Immunol. 131:984-990.

37. Williams, D. M., J. R. Graybill, and D. J. Drutz. 1981. Adoptive transfer of immunity to Histoplasma capsulatum in athymic nude mice. Sabouraudia 19:39-48.

38. Williamson, B. D., E. A. Carswell, B. Y. Rubin, J. S. Prendergast, and L. J. Old. 1983. Human tumor necrosis factor produced by human B-cell lines: synergistic cytotoxic interaction with human interferon. Proc. Natl. Acad. Sci. USA 80:53975401.

39. Worsham, P. L., and W. E. Goldman. 1988. Quantitative plating of Histoplasma capsulatum without addition of conditioned medium or siderophores. J. Med. Vet. Mycol. 26:137-143.

40. Wu-Hsieh, B. 1989. Relative susceptibility of inbred mouse strains C57BL/6 and $\mathrm{A} / \mathrm{J}$ to infection with Histoplasma capsulatum. Infect. Immun. 57:3788-3792.

41. Wu-Hsieh, B., and D. H. Howard. 1984. Inhibition of growth of Histoplasma capsulatum by lymphokine-stimulated macro- 
phages. J. Immunol. 132:2593-2597.

42. Wu-Hsieh, B., and D. H. Howard. 1987. Inhibition of intracellular growth of Histoplasma capsulatum by recombinant murine gamma interferon. Infect. Immun. 55:1014-1016.

43. Wu-Hsieh, B., and D. H. Howard. 1989. Histoplasmosis, p. 199-225. In R. A. Cox (ed.), Immunology of the fungal diseases. CRC Press, Inc., Boca Raton, Fla.

44. Wu-Hsieh, B., and D. H. Howard. 1990. Gamma interferon and experimental murine histoplasmosis, p. 135-146. In E. M. Ayoub, G. H. Cassell, W. C. Branche, Jr., and T. J. Henry (ed.), Microbial determinants of virulence and host response. American Society for Microbiology, Washington, D.C.

45. Wu-Hsieh, B., D. H. Howard, and R. Ahmed. 1988. Virusinduced immunosuppression: a murine model of susceptibility to opportunistic infection. J. Infect. Dis. 158:232-235.

46. Wu-Hsieh, B., and M. Ponsillo. 1988. Unpublished data. 